\title{
Role of Forensic Historical and Archaeological Examination in Preserving Archaeological Heritage
}

\author{
Kateryna Sylenok \\ ORCID: 0000-0001-9355-5010 \\ National Scientific Center "Hon. Prof. M. S. Bokarius \\ Forensic Science Institute”, Ukraine \\ sylenokkateryna@gmail.com
}

\section{Abstract}

The article covers the topic of the possibility of conducting forensic historical and archaeological examination. The problems that arise when protecting archaeological monuments are relevant not only for Ukraine but also for many countries of the world. Preserving history is an important task for every civilized country. To ensure effective protection of historical heritage of Ukraine, it is necessary to have effective mechanisms to prevent and protect archaeological monuments against destruction and theft. Formation and development of forensic historical and archaeological examination is essential to improve Ukrainian legislation, including the field of forensic science. To effectively apply state policy on the issues of archaeological monuments preservation while pre-trial investigation of criminal offenses, it is necessary to make an active use of special knowledge in the field of historical and archaeological research. One of the peculiarities of forensic research is that it should be performed in compliance with appropriately approved expert methods, characterised by combining in itself the necessary requirements for research and being the basis for quality and speed for solving forensic examination tasks. In this regard, their study and development are significant in research and practice. The aim of the article is to study the role of forensic historical and archaeological examination in preservation of archaeological heritage. It analyses the respective literature and legislation of Ukraine dedicated to forensic examination, forensic historical and archaeological examination and international experience in the field of archaeology.

Keywords: archaeological heritage, archaeological monuments, forensic historical and archaeological examination, protection of archaeological heritage in Ukraine. 


\section{Introduction}

Archaeological heritage is an inexhaustible resource for studying history and culture of the past which requires protection from criminal offenses. Information on archaeological discoveries is usually not widespread, therefore the public is not always aware of the importance of each. Simultaneously, illegal archaeological excavations have become more common recently, resulting in priceless artifacts of the past becoming part of private collections, and being destroyed due to negligence and violation of excavation requirements.

Currently, archaeological discoveries are of a great historical, cultural, social and educational significance. Despite the enormous value of each artefact for the state and people who are heirs of ancient tribes as well as for people having created civilization at Ukrainian land, the archaeological heritage of Ukraine is constantly lost. It is looted by black archaeologists who irreparably damage it, eliminating the historical context of the discovery.

The main goal in the field of preserving archaeological heritage is to create conditions for organisational-legal, financial-economic and scientific support for protection and research of archaeological monuments (sites) in the interests of dynamic socio-economic, cultural and spiritual development of society. Archaeological discoveries, if skilfully presented, can enormously contribute to the development of tourism in Ukraine.

In the course of research, analysis of scientific publications, prior scientific developments, Ukrainian legislation and international experience in terms of the addressed issue was carried out. To fulfil the set goal, the article uses general scientific methods, in particular methods of formal logic (analysis, synthesis, deduction, induction, analogy, abstraction); comparative-law, system-structural method, etc.

Certain aspects of state policy regarding protection of cultural heritage are covered in scientific papers by V. I. Akulenko, R. V. Aseikin, M. M. Herasymov, O. S. Batishcheva, Yu. P. Bohutskyi, V. V. Karlova, T. V. Kurylo, O. V. Malysheva, M. O. Mishchenko, V. O. Navrotskyi, B. M. Odainyk, I. H. Poplavskyi, I. V. Pyvovar, S. S. Ptukha, O. S. Sotula, O. V. Usenko, M. I. Khavroniuk and others. Topicality of the research has been supported by Huliakov (Huliakov, 2020).

The aim of the article is to study the role of forensic historical and archaeological examination in preserving archaeological heritage.

\section{Research Results and Discussion}

Archaeological monuments are destroyed at a rapid rate due to negligent economic activity which constantly expands its boundaries (laying of pipelines and communications, highways, urban renewal, private building, etc.). This determines the scope and terms of researches, sets new tasks regarding quality and informativity and requires new approach to research methodology. Formerly, the field season began in late April, 
currently research is carried out throughout the year, occasionally under snow, because land acquisition and construction are performed throughout the year. Scheduled research with the purpose of preserving monuments and performing scientific study are conducted only as fieldwork of students and execution of programmes and projects financed by funds due to lack of adequate public funding. For this reason, an important role is now given to scientific and rescue research (excavations, supervision of earthworks), the method of its conduct, which allows to obtain more wholistic and high-quality information about archaeological monuments (Minaieva, 2010).

Strict compliance with legislation on protection of archaeological heritage in practical activity of state bodies, institutions, officials, enterprises is significant for preservation of national cultural heritage, where archaeological monuments serve as important components. In Ukraine, the right to conduct research on cultural heritage is enshrined in the current legislation: archaeological expedition may be established by the Institute of Archaeology and corresponding research institutions of NAS of Ukraine (which have archaeological departments), higher education institutions of the III or IV level of accreditation of state ownership within training programmes for students, by administrations of historical and cultural reserves, museums of state and communal ownership, staffed by archaeologists with appropriate qualifications, duly documented (part three of Article 14 of the Law On Protection of Archaeological Heritage). The Institute of Archaeology of NAS of Ukraine provides for the right to organise and perform scientific and scientificrescue research on archaeological monuments (Paragraph 2 of Article 12 of the Law of Ukraine On Protection of Archaeological Heritage) (Minaieva, 2020).

According to the Law of Ukraine On Protection of Archaeological Heritage in force on March 18, 2004, archaeological heritage of Ukraine is a set of archaeological heritage monuments under state protection and the associated territories, as well as movable valuable cultural artefacts (archaeological objects) which derive from archaeological monuments (Rada, 2004).

A separate section of the Law of Ukraine On Protection of Cultural Heritage regulates rules for monument protection. Thus, according to Article 22 of the Law, monuments, their parts, related movable and immovable property are prohibited to be demolished, changed, replaced, moved (relocated) to other places. Moving (relocating) the monument to another place is allowed as an exception in cases when it is impossible to keep the monument in place, provided a set of researches on the study and fixation of the monument (measurements, photofixation, etc.) is carried out (Rada, 2000). Violators of the Law are liable considering the established guilt and the caused damage.

Thus, the Code of Ukraine on Administrative Offenses in 2001 was supplemented by Article 921 Violation of the Legislation on the National Archival Fund and Archival Institutions. Under the sanction of Part 1 of this Article, negligent storage, damage, illegal destruction, concealment, illegal transfer of archival documents to another person, violation of the procedure for access to these documents, as well as failure to notify the state archival institution of existing archival documents in case of emergence 
Kateryna Sylenok. Role of Forensic Historical and Archaeological

Examination in Preserving Archaeological Heritage

of threats of destruction or significant deterioration of their condition: entail warning or imposition of a fine on citizens from three to seven tax-free minimum incomes and warning or imposition of fines on officials: from five to ten tax-free minimum incomes (Rada, 1984).

According to Part 2 of the same Article, the same actions committed by a person who during the year was subjected to administrative penalty for one of the violations stipulated in Part 1 of this Article: entail the imposition of a fine on citizens from seven to twenty tax-free minimum incomes of citizens, and on officials: from ten to forty tax-free minimum incomes (Rada, 1984). In addition, Article 92 of the Code of Administrative Offenses provides for liability for violation of the legislation requirements on cultural heritage protection. Violations entail the imposition of a fine on citizens from fifty to one hundred tax-free minimum incomes and on officials: from one hundred to one hundred and fifty tax-free minimum incomes (Myshchak, 2013).

To protect archaeological heritage, Ukrainian legislation provides for the holding of a set of measures by relevant public authorities, their officials, enterprises, institutions, organisations and citizens. Measures should be aimed at accounting, protection, preservation, proper maintenance, proper use, conservation, restoration, rehabilitation and museumification of archaeological monuments, as well as dissemination of knowledge about archaeological heritage.

One of the mechanisms for protection of archaeological heritage is the criminal liability provided for in Article 298 of the Criminal Code of Ukraine for illegal excavations at archaeological heritage site, destruction or damage to cultural monuments (Rada, 2001a). In the course of a criminal proceeding, the investigator must gather corresponding, admissible, reliable evidence, which collectively will be sufficient for the court to impose sentence. The source of evidence is the conclusion of a forensic archeologist who is empowered to objectively evaluate the amount of the caused damage, presence or absence of historical or archeological monuments, determine cultural value of the object, etc. It is impossible for the investigator to independently, without a help of a specialist, establish whether the archaeological monument was damaged; whether seized movable objects originate from archeological monuments; what the amount of damage is. In such case, involvement of a forensic expert is of great importance.

Damage is caused as a result of activities of natural and legal persons. In his report, Hlib Yuriiovych Ivakin, a corresponding member of the National Academy of Sciences of Ukraine, notes that targeted efforts have been made on behalf of construction entities to destroy Ukrainian current legislation on protection of archaeological heritage particularly since 2009 (Ivakin, 2013). As a result of the adoption of the Law of Ukraine On Regulation of City Planning Activity, the Land Code of Ukraine as well as the Laws of Ukraine On Protection of Cultural Heritage and On Protection of Archaeological Heritage have been amended and the control mechanism for construction and excavation has been practically destroyed. At present, cultural heritage authorities are effectively suspended from approving construction projects located outside protected areas of monuments or 
historical sites. That is, although on paper, a very small percentage of cultural heritage is under protection (Ivakin, 2013).

$\mathrm{H}$. Yu. Ivakin also brings attention to the fact that the only complex of national archaeological heritage is artificially divided into "monuments", that is archaeological heitage monuments registered by the Ministry of Culture and Information Policy of Ukraine. Not yet identified and unregistered archeological monuments are practically not protected by the state. Cultural heritage is uncontrollably susceptible to construction work, transferred to private ownership, and in fact is destroyed. Approval of projects without a forensic archaeologist is transformed into bureaucratic formality (Ivakin, 2013).

Such a challenging situation with desctruction of archeological monuments is observed not only in Ukraine. For example, Andris Kairiss in his article Awareness Raising and Protection of Archaeological Heritage drew attention to similar problems in Latvia. In this article, the scientist provides statistics on damages caused to the national archaeological heritage. Besides, A. Kairiss offers an example of how three offenders were convicted in Latvia for damaging and robbing ancient burial site. This fact could be considered a positive indicator; however, then it was the first case when criminals were prosecuted and sentenced for such offense. It is also stated in the article that there are no statistics on the actual state of destruction and theft of monuments (Kairiss, 2017).

The above circumstances demonstrate the need for a more decisive approach to solving the problem of monuments destruction. It should be stressed that creation of a concept for development of forensic historical and archeological examination, given the international trends, would be an effective impetus for the development of this area. In this regard, O. Agapova in her research paper draws attention to the position of researchers that all green papers (doctrines, concepts, strategies, etc.) without exception determine the promising areas for public policy development in any area of state activity. Due to absence of clear and systematic vision for the development concept of the field of justice expert support in Ukraine, the research topic dedicated to the analysis of the state of development of public policy guiding documents, scientific understanding and formulation of proposals to improve the functioning of the field of justice with the prospect of their enshrinement in green papers are updated (Agapova, 2020).

Each state must ensure preservation of historical monuments for future generations, and currently Ukraine is actively promoting this area. The staff of National Scientific Centre "Hon. Prof. M. S. Bokarius Forensic Science Institute" (HNIISE) developed suggestions for creation of a new direction of forensic examination and a corresponding expert specialisation, developed training programmes for forensic experts in the field of forensic historical and archaeological examination. As a result of a long and dilligent work of scientists, the proposal to create a new expert area is supported at the legislative level. 
According to the Order of the Ministry of Justice No 243/5 On Approval of Amendments to Certain Legal Regulations on Forensic Examination dated on January 20, 2021, changes were made to the List of types of forensic examinations and expert specialisations for which the qualification of a forensic expert was awarded to specialists from forensic science institutes of the Ministry of Justice of Ukraine, namely, the list was supplemented by a new specialization: historical and archaeological examination of land (Rada, 2021). Since 2021, forensic examinations have been carried out in the area: historical and archaeological examination of land at National Scientific Centre "Hon. Prof. M. S. Bokarius Forensic Science Institute" (HNIISE). Forensic historical and archaeological examination is an essential element in the mechanism on protection and preservation of archaeological sites.

The factual basis for the appointment of forensic examination is the need for scientific, technical or other special knowledge required to address certain issues in criminal proceedings and other types of court proceedings. Special knowledge includes knowledge in a particular field of science, technology, art or craft and in other specific areas of human activity.

Obtaining expert conclusion is one of the ways to gather evidence in criminal proceedings. Therefore, the investigator or prosecutor, as a rule, involves a forensic expert depending on the availability of grounds at his discretion, based on specific circumstances of a proceeding and questions to be answered by a specialist in a particular field of knowledge (Bondarenko, 2017).

Monuments of forensic archaeological and historical examination are land plots with physical evidence of people existence in the past epochs regardless of the state of their preservation (kurgans, burial sites, necropolises, hillforts, settlements, separate graves, houses, household outbuildings and their remains; anthropogenic layers and movable archaeological objects detected in them) as well as accounting records and research documentation on historical (located underground) and/or archaeological monuments of cultural heritage.

The main tasks of historical and archaeological examination of land are:

- determination of the presence / absence of archaeological and historical heritage within the land;

- determination of the presence/absence of the object of archaeological heritage monument protection within the land plot;

- assignment of archeological heritage monuments to a certain chronological group, establishment of its cultural value of historical significance, level of rarity and preservation, attribution of archeological objects and calculation of costs for works on monument archeological research (addressed while identification of archaeological heritage monuments within the land plot and/or complex appraisal-construction, historical-archaeological and art examination when calculating the value of the monument and/or establishing the amount of damage caused to the state due to destruction, devastation or damage to archaeological heritage monuments); 
- determination of the presence / absence in the accounting documentation on historical (located beneath the earth's surface) and / or archaeological cultural heritage monuments of materials on carried out researches, factual data on the authenticity and subject of protection and other tasks. (HNIISE, 2021).

The absence in the Order of the Ministry of Justice of Ukraine No 53/5 On Approval of the Instruction on Appointment and Conduct of Forensic Examinations and Expert Researches dated on 08.10.1998 and Scientific and methodological recommendations on preparation and appointment of forensic examinations and expert researches of an indicative list of issues solved by forensic and archeological examination of land remains a pressing issue.

Staff of National Scientific Centre "Hon. Prof. M. S. Bokarius Forensic Science Institute" (HNIISE) proposes the following list:

- Is there archaeological or historical heritage monument within the land plot?

- Is there an object of legal protection for archaeological heritage monument within the land plot?

- Does archaeological heritage site that is not found in terrestrial amounts and located within the land plot require research on the entire area and throughout the entire depth of the cultural layer?

- Has an archaeological monument that had not been identified in terrestrial amounts in the entire area and throughout the entire depth of the cultural layer been researched on, while cultural heritage monuments that are the subject to conservation or museumification on-site and for further use had not been identified?

- Has the archaeological heritage monument lost its legal protection?

- What are the boundaries of the identified and/or damaged archaeological or historical heritage monument, which chronological group does it belong to, what are its coefficients of cultural value, historical significance, level of rarity and preservation?

- What is the total cost for archaeological researches?

- What is the attribution of archaeological objects found during excavations or after/during damage or destruction of archaeological heritage monuments?

- Do accounting records on historical (subterranean) and / or archaeological cultural heritage monuments contain materials on performed research, factual data on the authenticity and availability of the subject of protection?

- Are / not there data in research materials that the archaeological heritage monument within the land plot has been studied throughout the entire area and the whole depth of the cultural layer and at the same time no cultural heritage monuments are identified, which are subject to conservation or museumification on-site and to further use?

Historical and archaeological examination of land plots can solve other issues, if special knowledge in the field of archaeology and history is required to solve set tasks (HNIISE, 2021). 
The next stage in the development of forensic historical and archaeological examination should be the development of a corresponding methodological support. The methodology of expert research is an essential feature of each type of examination. It is determined by the nature of studied objects and necessitates the use of a certain system (set) of methods. Methods and technical means of examination are borrowed from natural, engineering and other sciences. In expert research, they are applied in a transformed form, given the specifics of examination objects. Simultaneously, their neither mechanical involvement in expert technique nor basic borrowing take place, but synthesis, transformation in accordance with a peculiar focus of their use. A general theoretical set of techniques and methods is not yet a methodology, although it constitutes the needed content. This is only a possibility of methodology as a "tool" for practical activity of a forensic expert. Methodology is a system of methods that is organised in terms of a specific goal, objectives, research opportunities (Bilenchuk, Kovalova, Shulha, \& Strilets, 2013).

The main function of any expert methodology is aimed at achieving a direct research purpose: to establish facts that have probative value. The Law of Ukraine On Judicial Examination stipulates that methodologies of conducting forensic examinations (except forensic-medicine and forensic-psychiatric) are subject to certification and state registration in the procedure determined by the Cabinet of Ministers of Ukraine.

According to the Resolution of the Cabinet of Ministers of Ukraine No 595 On Approval of the Procedure for Certification and State Registration of Methodologies for Conducting Forensic Examinations dated on 02.07.2008, the term "method of conducting forensic examination should be understood as the result of scientific work containing a system of research methods used while subsequent actions of a forensic expert to fulfil a specific expert task" (Rada, 2008). After attestation of methodologies, their state registration takes place by entering in the Register of methods of forensic examinations used while expert researches.

Given that the process of developing methodologies is statutory regulated, they (methodologies) after corresponding procedures are entered into the State Register of methods of forensic examinations (Zvit pro naukovo-doslidnu robotu ..., 2020).

Creation of new methodologies is a creative process based on understanding the laws of the process of features formation on studied objects, identification of these features using certain tools and methods.

The specific purpose of creating new methods is to expand the amount of factual data provided to the investigation and court based on the ability to solve new tasks, research on new objects, reduce the timing of forensic examinations, material and labour costs, reduce unresolved issues, increase scientific quality and thoroughness in solving expert tasks (Pyrih, 2011).

For expert methodologies in the process of their application to ensure timely, thorough and comprehensive identification and understanding of facts and 
circumstances; solution of both typical and non-standard tasks of expert research; effective application of techniques and methods, as well as a successful overcoming of various obstacles in the course of expert research with the least efforts and resources, the methodology developer must go through certain stages in the course of its creation (Slobodian, 2013).

One of the significant elements for a favourable development of forensic historical and archaeological examination is the achievement of a certain level of harmonisation of the legislation of our country with international legal norms. The importance of international agreements as sources of legislation is due to the fact that such agreements, in particular the Convention of UNESCO (UNESCO, 1972) and the Council of Europe, establish general principles and frameworks of global and European policy with which national policy and inheritance law should be agreed upon.

According to Article 9 of the Constitution of Ukraine, current international agreements, the binding nature of which has been approved by the Higher Rada of Ukraine, are part of the national legislation of Ukraine. It should also be emphasised that Article 19 of the Law of Ukraine On International Agreements of Ukraine prioritises provisions of international agreements that have entered into force for Ukraine over provisions of other acts of its legislation (Analiz problem ..., 2018).

Cooperation in the field of historical and archaeological researches is provided by national legislation (for example, in the Law of Ukraine On Protection of Archaeological Heritage (Article 21)) (Rada, 2004), current international agreements of Ukraine with foreign countries in the field of scientific cooperation.

International cooperation in the field of archaeology is ensured by a number of international regulatory legal documents: European Convention on the Protection of the Archaeological Heritage (Rada, 1992); The Convention on the Protection of the Underwater Cultural Heritage (Rada, 2001); The Convention for the Protection of the Architectural Heritage of Europe (Rada, 1985) and others.

However, the UNESCO Convention Concerning the Protection of the World Cultural and Natural Heritage plays a crucial role in preservation of cultural and natural heritage in all regions of the world. It was adopted at the $17^{\text {th }}$ session of the UNESCO General Conference in Paris in 1972 (UNESCO, 1972). According to the Convention Concerning the Protection of the World Cultural and Natural Heritage adopted in 1972, its member countries admit that protection of the world heritage is the responsibility of the entire international community. The attitude towards preserving cultural and natural heritage reflects the cultural level of society. The protection of monuments is not limited only to restoration: it is a phenomenon that intertwines the political, economic, legal, moral and ethical processes that the world, every country, civil society live by. Monuments are inseparable from society, they are formed within it, evaluated, preserved or destroyed by it (Prokaieva, 2011). 


\section{Conclusions}

Existing regulatory and legal framework establishes a mechanism for monument protection at legislative level, but its implementation is not efficient. Provisions of the Laws of Ukraine On Protection of Archaeological Heritage, On Protection of Cultural Heritage, On Regulation of City Planning Activity, the Code of Ukraine on Administrative Offenses, the Criminal Code of Ukraine are dedicated to archaeological heritage. At international level, these issues are governed by the UNESCO Convention Concerning the Protection of World Cultural and Natural Heritage, European Convention on the Protection of the Archaeological Heritage, the Convention on the Protection of Underwater Cultural Heritage, Convention for the Protection of the Architectural Heritage of Europe, etc.

This reflects the interest of the international community in archaeological heritage preservation.

The development of forensic historical and archaeological researches in Ukraine and their active application in practice is an essential element in the mechanism of protection and preservation of archaeological monuments. Considering international experience and reaching a certain level of harmonisation of the legislation of Ukraine with international legal norms will contribute positively to the development of forensic historical and archaeological examination.

Forensic historical and archaeological examination is an important element in the mechanism of protection and preservation of archaeological monuments. For its efficiency, methodologies, the availability of which is a significant feature of each type of forensic examination, should be implemented. Such methodologies must be entered in the State Register of Methods of Forensic Examinations.

Obtaining an expert conclusion is one of the ways to gather evidence in criminal proceedings. Therefore, the investigator or prosecutor, as a rule, involves a forensic expert depending on the availability of grounds at his discretion, based on specific circumstances of a proceeding and questions to be answered by a specialist in a particular field of knowledge. In the decision on the appointment of a forensic expert the list of questions addressed to the forensic expert must be indicated. It is expedient to supplement the Order of the Ministry of Justice of Ukraine No 53/5 On Approval of the Instruction on Appointment and Conduct of Forensic Examinations and Expert Researches dated on 08.10.1998 and Scientific and methodological recommendations on preparation and appointment of forensic examinations and expert researches by information on archaeological and historical examination. 
Kateryna Sylenok. Role of Forensic Historical and Archaeological Examination in Preserving Archaeological Heritage

\section{Bibliography}

1. Agapova, O. V. (2020). Shchodo neobhodimosti rozrobky kontseptsii rozvytku sfery ekspertnoho zabezpechennia pravosuddia v Ukraini. Visnyk Kharkivskoho natsionalnoho universytetu imeni V. N. Karazina. Seriia "PRAVO”. 29, 162-168.

2. Analiz problem u zakonodavchomu rehuliuvanni zabezpechennia ta upravlinnia kulturnoiu ta pryrodnoiu spadshchynoiu v Ukraini. (2018). Pidhotovleno ekspertamy Vseukrainskoi Merezhi OHS dlia pidtrymky hromad zi spadshchynoiu pid zahalnoiu redaktsiieiu Kyryla Rubanovskoho. Ivano-Frankivsk. P. 158.

3. Bilenchuk, P. D., Kovalova, V. V., Shulha, O. O., Strilets, H. A. (2013). Suchasna klasyfikatsiia metodiv sudovoi ekspertyzy. Kriminalistika i sudebnaia ekspertiza. 58(2), 118-123. http://nbuv. gov.ua/UJRN/krise_2013_58\%282\%29_24.

4. Bondarenko, O. O. (2017). Okremi pytannia vykorystannia spetsialnykh znan u kryminalnomu provadzhenni. Visnyk KhNUVS - Bulletin of KhNUIA. 3 (78), 51-59.

5. Huliakov, K. (2020). Evoliutsiia zakonodavstva pro okhoronu obiektiv istorychnoi ta kulturnoi spadshchyny protiahom KhKh stolittia. Yurydychnyi Visnyk, 4, 240-246. http://yurvisnyk.in.ua/ v4_2020/31.pdf; DOI https://doi.org/10.32837/yuv.v0i4.1994.

6. Ivakin, H. Yu. (2013). Problemy okhorony ta zberezhennia arkheolohichnykh pamiatok v Ukraini. Visnyk NAN Ukrainy, 5, 86-88. http://dspace.nbuv.gov.ua/handle/123456789/67310.

7. Kairiss, A. (2017). Awareness Raising and Protection of Archaeological Heritage. https:// www.researchgate.net/publication/344043856_Awareness_Raising_and_Protection_of_ Archaeological_Heritage.

8. KNDISE. (2021). Istoryko-arkheolohichna ekspertyza. https://www.hniise.gov.ua/14683-storikoarxeologchna-ekspertiza.html.

9. KNDISE. (2020). Zvit pro naukovo-doslidnu robotu "Aktualizatsiia metodychnykh rekomendatsii "Rozrobka ekspertnykh metodyk: zmist, struktura, oformlennia"”. 224 s.

10. Minaieva, N. (2020). Suchasna zakonodavcha baza shchodo zberezhennia i doslidzhennia obiektiv arkheolohichnoi spadshchyny Ukrainy. Arkheolohichni doslidzhennia v Ukraini 2019. Kyiv. P. 10-12.

11. Minaieva, N. I. (2010). Naukovo-riativni doslidzhennia viddilu davnoruskoi i serednovichnoi arkheolohii Instytutu arkheolohii NAN Ukrainy. Arkheolohiia i davnia istoriia Ukrainy: Zb. nauk. pr. Kyiv. IA NAN Ukrainy. Vyp. 1. P. 502-506.

12. Myshchak, I. M. (2013). Zakonodavche zabezpechennia okhorony kulturnoi spadshchyny ta shliakhy yoho vdoskonalennia v Ukraini. Naukovi zapysky Instytutu zakonodavstva Verkhovnoi Rady Ukrainy. № 3. P. 31-36. http://nbuv.gov.ua/UJRN/Nzizvru_2013_3_8.

13. Prokaieva, V. V. (2011). Rol YuNESKO u zberezhenni kulturnykh nadban liudstva. Aktualni problemy mizhnarodnykh vidnosyn. 103 (I), 209-217.

14. Pyrih, I. V. (2011). Teoretychni osnovy ekspertnoi diialnosti orhaniv vnutrishnikh sprav: monohrafiia. Dnipropetrovsk: Dniprop. derzh. un-t vnutr. sprav; Lira LTD. 312 s.

15. Rada. (2021). Pro zatverdzhennia Zmin do deiakykh normatyvno-pravovykh aktiv z pytan sudovo-ekspertnoi diialnosti: nakaz Miniustu Ukrainy № 243/5. 20.01.2021. https://zakon.rada. gov.ua/laws/show/z0089-21\#n155.

16. Rada. (2004). Zakon Ukrainy: Pro okhoronu arkheolohichnoi spadshchyny № 1626-IV. 18.03.2004 (redaktsiia vid 12.12.2012). https://zakon.rada.gov.ua/laws/show/1626-15\#Text. 
Kateryna Sylenok. Role of Forensic Historical and Archaeological

Examination in Preserving Archaeological Heritage

17. Rada. (2001). Konventsiia pro okhoronu pidvodnoi kulturnoi spadshchyny: pryiniata YuNESKO 02.11.2001, ratyfikovana Zakonom Ukrainy vid 20.09.2006 № 164-V. https://zakon.rada.gov.ua/ laws/show/995_c52\#Text.

18. Rada. (2001a). Kryminalnyi kodeks Ukrainy: Zakon Ukrainy № 2341-III. 05.04.2001, (zi zminamy ta dopovnenniamy). https://zakon.rada.gov.ua/laws/show/2341-14\#Text.

19. Rada. (2000). Zakon Ukrainy: Pro okhoronu kulturnoi spadshchyny № 1805-III. 08.06.2000. https://zakon.rada.gov.ua/laws/show/1805-14\#\#Text.

20. Rada. (1992). Yevropeiska konventsiia pro okhoronu arkheolohichnoi spadshchyny: pidpysana 16.11.1992, ratyfikovana Zakonom Ukrainy vid 10.12.2003 r. № 1369VIV. https://zakon.rada. gov.ua/laws/show/994_150\#Text.

21. Rada. (1988). Konventsiia pro okhoronu vsesvitnoi kulturnoi i pryrodnoi spadshchyny: pidpysana 16 lystopada1972; ratyfikovana Ukazom prezydii Verkhovnoi rady Ukrainskoi RSR vid 4 zhovtnia 1988 N 6673-XI. https://zakon.rada.gov.ua/laws/show/995_089\#Text.

22. Rada. (1985). Konventsiia pro okhoronu arkhitekturnoi spadshchyny Yevropy: pryiniata 03.10.1985 r., ratyfikovana Zakonom Ukrainy vid 20.09.2006 r. № 165-V. https://zakon.rada. gov.ua/laws/show/994_226\#Text.

23. Rada. (1984). Kodeks Ukrainy pro administratyvni pravoporushennia № 80731-X, 07.12.1984. (u redaktsii vid 08.08.2021). https://zakon.rada.gov.ua/laws/show/80731-10\#Text.

24. Slobodian, Ya. I. (2013). Metodyky provedennia sudovykh ekspertyz: problemno-oriientuvalnyi analiz. Borotba z orhanizovanoiu zlochynnistiu i koruptsiieiu (teoriia i praktyka). $1(29$,$) 265-272.$ 